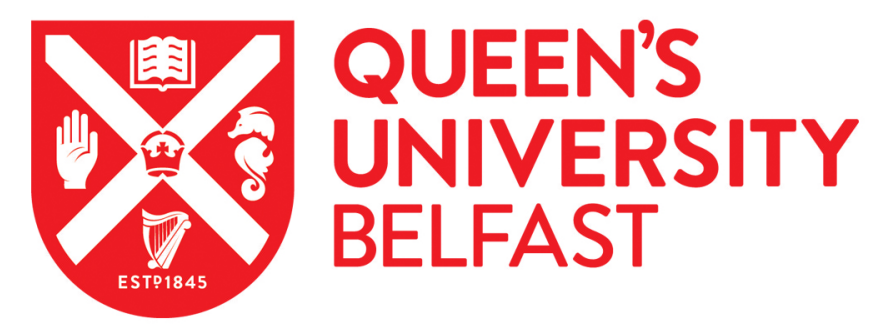

\title{
Max Weber and the First World War: Protestant and Catholic living standards in Germany, 1914-1919
}

Blum, M., \& Strebel, M. (2016). Max Weber and the First World War: Protestant and Catholic living standards in Germany, 1914-1919. Journal of Institutional Economics, 12(3), 699-719.

https://doi.org/10.1017/S1744137415000533

Published in:

Journal of Institutional Economics

Document Version:

Peer reviewed version

Queen's University Belfast - Research Portal:

Link to publication record in Queen's University Belfast Research Portal

Publisher rights

(C) 2016 Millennium Economics

This version is free to view and download for private research and study only. Not for re-distribution, re-sale or use in derivative works.

\section{General rights}

Copyright for the publications made accessible via the Queen's University Belfast Research Portal is retained by the author(s) and / or other copyright owners and it is a condition of accessing these publications that users recognise and abide by the legal requirements associated with these rights.

Take down policy

The Research Portal is Queen's institutional repository that provides access to Queen's research output. Every effort has been made to ensure that content in the Research Portal does not infringe any person's rights, or applicable UK laws. If you discover content in the Research Portal that you believe breaches copyright or violates any law, please contact openaccess@qub.ac.uk. 


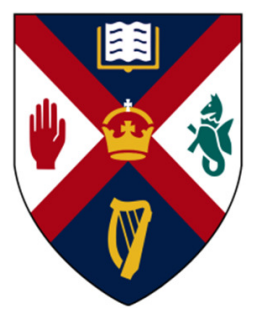

QUEEN'S MANAGEMENT SCHOOL
ECONOMICS WORKING PAPER SERIES https://ideas.repec.org/s/qub/wpaper.html

MAX WEBER AND THE FIRST WORLD WAR: PROTESTANT AND CATHOLIC LIVING STANDARDS IN GERMANY, 1915-1919

Matthias Blum (Queen's University Belfast) Matthias Strebel (Technische Universität München)

Working Paper 2015-04

December 2015

QUEEN'S MANAGEMENT SCHOOL Queen's University Belfast

185 Stranmillis Road

Belfast BT9 5EE 


\title{
Max Weber and the First World War: Protestant and Catholic
}

\section{living standards in Germany, 1915-1919}

\author{
Matthias Blum ${ }^{1}$ and Matthias Strebel ${ }^{2}$
}

\begin{abstract}
We assess informal institutions of Protestants and Catholics by investigating their economic resilience in a natural experiment. The First World War constitutes an exogenous shock to living standards since the duration and intensity of the war exceeded all expectations. We assess the ability of Protestant and Catholic communities to cope with increasing food prices and wartime black markets. Literature based on Weber $(1904,1905)$ suggests that Protestants must be more resilient than their Catholic peers. Using individual height data on some 2,800 Germans to assess levels of malnutrition during the war, we find that living standards for both Protestants and Catholics declined; however, the decrease of Catholics' height was disproportionately large. Our empirical analysis finds a large statistically significant difference between Protestants and Catholics for the 1914-19 birth cohort, and we argue that this height gap cannot be attributed to socioeconomic background and fertility alone.
\end{abstract}

Keywords: Germany; First World War, Religion, Protestantism; Catholicism; Economic History; anthropometrics; biological standard of living; height; stature.

JEL codes: N14; I20; I30

Acknowledgements: The authors thank Jörg Baten, Graham Brownlow, Francesco Cinnirella, Chris Colvin, Stuart Henderson, Liam Kennedy, Eoin McLaughlin, Renee Prendergast, seminar participants in Belfast, Freising and Mannheim, participant of the German Economic History Conference in Münster, participants of the workshop on Historical Economics and the Economics of Religion in Belfast, participants of the Dublin FRESH workshop as well as two anonymous reviewers for comments on earlier versions of this article.

\footnotetext{
${ }^{1}$ Queen's University Belfast. 185 Stranmillis Road, Belfast BT9 5EE, UK. Corresponding author: matthias.blum@qub.ac.uk.

${ }^{2}$ Technische Universität München. Alte Akademie 12, 85354 Freising, Germany.
} 


\section{Introduction}

More than a century after the publication of Max Weber's $(1905,1904)$ thesis on the existence of a Protestant "work ethic", research on the economics of religion is in full bloom. A series of studies has tried to provide empirical evidence for Weber's thesis, often within the scope of historical settings. Generally, researchers contribute to two competing strands of literature. The first concerns evidence that differences in social capital and social institutions result in differences in living standards between members of different denominations, such as the prevalence of networks, high incomes, accumulation of savings, resilience to risk, and the ability to cope with anonymous markets. The second strand argues that differences between Catholics and Protestants arise from different levels of human capital accumulation, i.e. education and skills.

This article aims to contribute to this inconclusive debate by exploiting a natural experiment in Germany during the First World War: the shortage of food and the emergence of black markets in war-affected and increasingly war-weary Germany. Apart from religious differences, the population in the area under observation is fairly homogenous, helping to rule out differences between test and control groups that may complicate cross-country comparisons. The economic responses of Protestant and Catholic communities to these harsh conditions may help to assess their relative abilities to cope with deteriorating material living conditions. Using terminal adult height data of some 2,800 Germans born before, during and after the First World War as a proxy for levels of early childhood nutrition, we find that Protestants were much less affected by deteriorating wartime living standards. Some of this advantage can be explained by differences in social status and fertility. However, we find a positive residual effect for Protestantism, suggesting that there are factors accompanying Protestantism that helped this societal group to fare considerably better than their Catholic peers during the war years, and these factors are unrelated to social status and fertility. 
This finding is also noteworthy from an economic history point of view since previous research largely ignored the role of institutions but highlighted the role of socioeconomic background to explain living standards in Germany during the First World War (Blum, 2013c, Cox, 2015). The findings presented in this article suggest that factors beyond socioeconomic background are important to understand the factors that helped German Protestants to cope relatively well with deteriorating nutritional conditions 1914-19.

This article proceeds as follows. The following section presents relevant literature on Protestant and Catholic social institutions and may help to interpret the findings presented in this article. Subsequent sections introduce the historical setting, especially the mechanisms leading to deteriorating living conditions in Germany during the First World War; the methodology and the dataset are discussed; and data are analyzed in order to gain insights into Protestant and Catholic wellbeing during the period under observation. The final section concludes.

\section{A selective literature review: Weber, Protestants and the black box}

This literature review intends to serve as a basis for interpreting and understanding differences in living standards between Catholics and Protestants in Germany before and during the First World War. Generally, there are studies emphasizing the role of socioeconomic background and human capital, and competing arguments based on social capital and institutions. Essentially, both arguments pick up Max Weber's (1905) argument which indicates that Protestants believe in achieving salvation through worldly activities favoured an ethic of hard work and frowned upon excessive consumption. These reformed beliefs may have changed the economic incentives of followers, ultimately encouraging participation in more productive economic activities, fostering savings behaviour, and increasing capital accumulation (Arruñada, 2010). 
One strand of literature disagrees with Weber's core thesis. With a focus on differences in education and human capital, it is argued that the superior skills of the Protestants lead to an advantage in terms of income and welfare. Most prominently, Becker and Woessmann (2009) test the Weber hypothesis in the case of $19^{\text {th }}$-century Prussia and do indeed find such a Protestant advantage. These authors conclude that it is the superior level of literacy among Protestants, and not their superior work ethic, driving this advantage. Similarly, Catholic districts in late $19^{\text {th }}$-century Switzerland show, on average, significantly lower educational performance and less expenditure on primary schooling compared to Protestant districts. Catholicism, however, seems to be harmful only in a conservative milieu, indicating that not all societal groups are affected (Boppart et al., 2013). The educational advantage of Protestants may date back as far as the publication of Martin Luther's German translation of the Bible, a time when the general population could develop literacy skills by reading the Bible (Boppart et al., 2014).

Another strand of literature is oriented towards the influence of Protestantism on social capital and institutions powerful enough to give one group an edge over the other, eventually leading to an observable difference in living standards. This literature adopts the position that effects related to human capital are only one influencing channel. For example, Schaltegger and Torgler (2010) argue that the question as to whether a Protestant-specific work ethic exists at all is rarely analysed, leaving much space for the existence of a Protestant work ethic. Using data from the European Values Survey, these authors provide evidence that both education and religiosity influence work ethic among Protestants, but not among Catholics. Similarly, La Porta et al. (1997) argue that trust, an important determinant of cooperation and trade between strangers in a society, is lower in societies with dominant hierarchical religions, such as Catholicism. Also, historically, Protestant societies have developed more interpersonal trust compared to Catholic societies, reducing transaction costs and fostering market-oriented 
activities (Arruñada, 2010, Inglehart, 1999). ${ }^{3}$ A potential consequence of this historical heritage may be reflected in Stulz and Williamson's (2003) finding that Catholic societies tend to do less to protect the rights of creditors than Protestant countries because of an alleged aversion towards usury. Similarly, Renneboog and Spaenjers (2012), using modern-day Dutch household data, find that Protestantism is correlated with greater financial responsibility; Catholic households tend to be more risk-averse and invest less in stock markets, putting a larger share of their money into savings. In a German case study, Spenkuch (2011) finds that Protestantism induces individuals to work longer hours, and leads thereby to higher earnings and institutional factors or differences in human capital acquisition cannot account for this effect. Using modern-day survey data on some 25,000 individuals from a series of countries, Arrunada (2010) finds little support for Weber's “work ethic" hypothesis. However, this author finds evidence for a "social ethic", as Protestant values seem to encourage individuals to be more active in mutual social control, more supportive of institutions and less bound to close circles of family and friends.

Moreover, it can be argued that an important feature of religious groups is their clubgood characteristic. According to club good theory, individuals can be excluded from the benefits offered by a certain community (club) unless they join. In terms of religion, this view suggests that only members of a certain religious group benefit from the aforementioned institutional advantages, thereby concentrating benefits to the members of that group, to the exclusion of non-members (Colvin, 2011, Iannaccone, 1998, Buchanan, 1965).

The enormous literature that has been inspired by Weber's (1904, 1905) 'Protestant Ethic' must not cloud the view on more critical contributions in this field. In fact, Weber's thesis has been subject to criticism since its initial publication. For example, Tawney (1926), a contemporary of Max Weber, argues that Weber underestimates the role of the Renaissance for

\footnotetext{
${ }^{3}$ Similarly, Fogel and Engerman (1974, p. 147) state that slave owners in the antebellum US 'sought to imbue slaves with a "Protestant" work ethic and to transform that ethic from a state of mind into a high level of production'.
} 
the emergence of economic and business-promoting ideas. Morishima's (1982) work on the role of the 'Japanese Ethos' in the rise of the Japanese economy suggests that Weber underestimated the ability of non-Protestant religions, such as Confucianism in Japan during the $19^{\text {th }}$ and $20^{\text {th }}$ centuries, to foster economic development. Weber, Morishima argues, acknowledges the rationalism of Confucianism, but according to his 'Protestant Ethic' only Puritan rationalism aims at controlling environmental conditions while Confucian rationalism only encourages individuals to accommodate themselves within given environmental conditions, presumably providing Protestants with superior growth enhancing institutions.

More recently, McCloskey (2010, p. 140ff) disagrees with Max Weber, arguing that an interplay of a set of bourgeois institutions fostered the rapid development of capitalism in the Western world. She argues that the sociology, i.e. the societal attitude towards businessmen in some European societies changed due to these institutional changes rather than investment behaviour and saving rates. As a result, governments changed their policies, helping merchants to protect their property rights and generating growth enhancing institutions (Acemoglu et al., 2005). Elsewhere, authors emphasise the importance of the Industrial Revolution for subsequent economic growth and the economic and institutional changes this event triggered (Allen, 2012, Fernihough and O'Rourke, 2014, Landes, 1969, North, 1994).

\section{The historical scenario: Germany before, during and after the First World War}

How does this evidence relate to Germany during the First World War? Given its unexpected duration, intensity and impact on trading patterns, the German economy was unable to withstand the war-imposed shock, blindsiding both Catholic and Protestant communities. In light of the differences between the religious groups, it is reasonable to assume that the two communities dealt with these circumstances differently. Germany during the First World War was a place where illicit markets flourished; trustworthy relationships and networks with a nearby farmer, black marketers or relevant authorities could open the opportunity to purchase 
additional foodstuffs illegally at obscene prices; such an ability may have meant the difference between modest scarcity and starvation. In as much, the most important assets during this period were social networks; high incomes; an accumulation of savings; and openness to risk-taking. Possessing these assets made it easier to use black markets to acquire the additional foodstuffs the official rationing system could not provide. According to the literature, these assets are predominantly held by Protestants.

During the years prior to the First World War, Germany's economic development had culminated. German GDP had grown considerably, both in absolute and per capita terms; population had grown in the order of 1.3 per cent per annum; and the country experienced rapid urbanization (Hoffmann et al., 1965). The agricultural sector substantially changed from a producer of agricultural products to a refiner, gradually moving towards producing superior dairy and meat products using imported feed. This transformation was an answer to changes in the domestic demand for foodstuffs; Germans experienced income increases and demanded superior animal-based foodstuffs - a common trend in emerging economies (Blum, 2013a, Baten and Blum, 2012).

The outbreak of war in 1914 resulted in a deterioration of living standards; this economic environment helps to isolate and assess Protestant and Catholic ability to adjust to changes in living standards. During the First World War (WWI), several factors created a challenge for society and the economy: mobilization reduced production capacities by absorbing the labor force, horses, and foodstuffs, thus reducing available resources and reallocating them away from consumption and towards war-relevant production (Broadberry and Harrison, 2005). In this regard, Offer (1989) argues that the First World War was "not only a war of steel and gold, but a war of bread and potatoes". It is also worth mentioning that Germany, as any warring party, was not prepared to wage a four-year war that demanded an unprecedented amount of resources - Germany had initially hoped to win the war within six weeks. Moreover, despite 
long-term planning and investment in armament, the exact time of the war's outbreak was unexpected (Broadberry and Harrison, 2005, Blum and Eloranta, (forthcoming)).

After 1914, external trade became increasingly difficult because of the British blockade and the fact that some important trading partners became either enemies or became involved in the war. This created a considerable challenge for the entire economy, especially for the agricultural and food industries. The import figures of raw and intermediate products, such as fertilizer, food, feed, and labor (seasonal workers), declined considerably (Huber and Fogel, 1920, Ritschl, 2005). Skalweit (1927) reports that net imports of pigs, grains, and margarine declined by 85,98 , and 81 per cent respectively between 1916 and early 1918 . Moreover, nitrogen imports were used in the production of explosives, resulting in neglect of the agriculture industry's need for the production of nitrogen-based fertilizer (Fehr, 2009). In addition, general conscription drained the labor forces of all industries, agriculture and food production being no exception. An estimated 40 per cent of the agricultural labor force was absorbed by mobilization (Huber and Fogel, 1920).

Consequently, resources used in the German economy were reallocated according to the needs of the war economy. Generally, resources became scarcer for civilian and intermediate industries, while war-relevant industries absorbed more resources. Ritschl (2005) for example reports that while production levels in war-relevant industries temporarily declined, in 1917 and 1918 their production exceeded pre-war levels. Among the industries with the most pronounced declines were residential construction and textiles, both of which served predominantly civilian purposes. Production of cereals and construction materials fell to 57 and 35 per cent of pre-war levels, while war-related industries such as mining, iron and steel, and non-ferrous metal production declined only modestly and in some cases increased (Ritschl, 2005, Kuczynski, 1947). Similarly, Baten and Schulz (2005) investigate corporate real profits between 1913 and 1917 and also find systematic differences between the aforementioned industries. Their results suggest that compared to pre-war levels, profits in war-relevant 
industries increased by 27 per cent (1916) and 14 per cent (1917). In particular, industries involved in the production of chemicals, metals, and machinery increased profits, while real profits in the food, tobacco, and textile industries declined by almost half. Similar evidence can be obtained by investigating wages paid in the aforementioned industries. In general, all industries were forced to increase wages in order to outweigh inflation. Industries producing civilian consumption goods, such as textiles, leather, rubber, beverages, food, and tobacco, grew proportionally less while wages in war-related industries grew at a disproportionate pace. Generally, Germany used a great deal of its economic capacity for military purposes on the expense of civilian consumption and investments (Zimmermann, 1932, Blum et al., 2013).

Fewer available resources and decreased imports to compensate for domestic shortages led to shrinking domestic production levels. Precise GDP estimates during the First World War differ, but it is safe to assume that production and national income declined somewhere around 30 per cent during the war. However, this average value underestimates the decline in production of foodstuffs and other consumption goods. Agriculture and food-related sectors especially suffered during the war economy. Flemming (1978) reports that while produced quantities of grains and potatoes increased prior to the war, production had fallen by a quarter by 1916 and by approximately half by 1918 compared with pre-war levels. For meat provision, evidence from the city of Dortmund suggests that official meat supply was held constant during the first half of the war, but it plummeted dramatically starting in the season 1916-17.

In Germany, like in other countries with low agricultural productivity, maximum prices were introduced and governments tried to purchase foodstuffs in the countryside at lower prices. In contrast, richer countries allowed for higher food prices, encouraging farmers to produce and market their production. In Germany, a great deal of foodstuffs was distributed via a rationing system in order to limit inequality and prevent social unrest (Broadberry and Harrison, 2005, Allen, 1998). However, rations, although well intended, provided only a fraction of pre-war consumption. During the growing season 1916/17, official consumption of potatoes and flour 
fell to 71 per cent and 53 per cent, respectively. Consumption of superior foodstuffs, such as meat, fish, and butter had fallen to 31 per cent, 51 per cent and 22 per cent, respectively. For most food items these levels could not be maintained; by late 1918 levels of flour and meat provision had fallen to 48 per cent and 12 per cent, respectively. A lot of effort was taken to maintain supply of basic foodstuffs, among others by slaughtering millions of hogs in 1915 to free potatoes for human consumption, resulting in consumed quantities of 94 per cent of prewar levels (table 1).

$$
\text { [place table } 1 \text { here] }
$$

Flemming (1978) discusses the share of calories provided via the rationing system and finds that the calorific values of rations were insufficient to meet minimum requirements. He estimates that for individuals performing light work, rations accounted for 58 to 74 per cent of energy requirements. In case of medium work, this share was 47 to 57 per cent, depending on ration volumes and body weight. Conversely, these estimates suggest that Germans had to find ways to acquire foodstuffs from other sources if they wanted to avoid starvation. Given scarcity of foodstuffs and the existence of maximum prices introduced by authorities the appearance of black markets was only a question of time, leaving authorities torn between protecting consumers and enabling markets to work efficiently. Natural prices (unofficial) and artificial prices (price ceiling) constantly diverged, increasing the incentive for agriculturalists to market their production unofficially. Comprehensive time series on black market prices are not available, but existing evidence suggests that unofficial prices increased throughout the war, both in absolute terms and relative to set price ceilings. For example, Lange (1929) reports official and unofficial food prices for the city of Essen between 1916 and 1918 (table 2). If the discrepancy of official and unofficial food prices can be used as an indicator for how appropriate price maxima reflect true scarcity, then Lange's (1929) figures suggest that prices for staple foods were set generally low, and over the course of time discrepancies increased, increasingly 
perverting production incentives and increasing incentives to engage in informal trade. For example, by 1918 the ratio between market and artificial prices had risen up to $6.5,18$, and 13 for potatoes, sugar, and eggs, respectively.

$$
\text { [place table } 2 \text { here] }
$$

The first notable signs of food shortages among children appeared during the autumn and winter of 1915-16. However, officials were urged not to publicize this information for the sake of morale and external presentation to the outside world. Only in 1917, when the low point in terms of food supply was reached, did reports from several German cities indicating nutritional deprivation become public. According to Siegmund-Schultze (1919), a contemporary observer, industrial cities in Saxony and Thuringia seem to have suffered most, indicating that the Western German evidence presented in this study is not an extreme example. ${ }^{4}$

Another result of the insufficient rations provided to Germans and the existence of flourishing black markets was the unequal development of living standards between different social classes. Empirical evidence suggests that the heaviest burden was borne by the middle and lower classes, whereas the upper class could almost maintain pre-war living standards. The latter benefitted from superior financial resources which enabled them to purchase scarce foodstuffs on informal markets (Blum, 2013c).

\section{Methodology and data}

The data base for this article does not allow precise tests for the nature of differences between these groups à la Arruñada (2010) who uses modern-day survey data to distinguish determinants of work ethic from those of social ethic in a series of countries. However, as Iannaccone (1998) states, religious data are often limited and unreliable since many aspects of religion are

\footnotetext{
${ }^{4} \mathrm{Cox}$ (2015) presents anthropometric evidence on a city level, indicating that nutritional deprivation occurred in the whole of Germany.
} 
inherently difficult to observe; this holds even more so for historical settings in which data compilation and quality cannot be influenced. Therefore, the test scheme applied in this study is centred on the level and variation of the average height trends, and a binary variable reflecting a residual effect for Protestants allows assessing living standards of Protestants and Catholics in Germany prior to and during the First World War. Height measurements of Germans are used as an indicator for average living standards. This approach is deemed more appropriate because average height is closely correlated to nutritional and health conditions during a cohort's early childhood and using a binary variable to distinguish Protestants and Catholics allows a precise and objective identification of the members of one of these societal groups (Robinson, 2013, Voigt, 2013a, Voigt, 2013b). The advantages of using anthropometric indicators are that these indicators reflect income earned through subsistence farming and black market activities, along with the insufficient reliability of official statistics (Steckel, 1995, Komlos and Baten, 2004). It is reasonable to assume that subsistence farming was generally practiced by farmers and their extended families during times of scarcity. German authorities permitted farmers to slaughter some of their livestock for private purposes (Hausschlachtungen), allowing for consumption beyond rations and the marketing of these products on black markets. Conversely, for consumers, illicit trading was necessary to use their purchasing power to acquire foodstuffs beyond the official rationing system. On this account, it is doubtful that income statistics are superior for describing living standards during the First World War in Germany. Given the existence of food rationing and black markets, average height is a more appropriate proxy of living standards than income or wage statistics, since socialist elements introduced to the German economy partially uncoupled purchasing power from consumption (Blum, 2011).

The rationale of this study is that differences in living standards - proxied by average height - of Protestants and Catholics can be traced before, during and after the First World War. If the literature on superior Protestant abilities is correct, then we expect that, controlling for 
other influencing factors, Protestants fared better during this period and that Protestants were affected less severely by war economy and food rationing. We aim at explaining any differences with a set of socioeconomic factors and expect that especially socioeconomic background and sibship size help to explain differences in height and living standards.

The data set used here contains data about lower-ranking German soldiers from NorthWest Germany (today located in North Rhine-Westphalia and Lower Saxony) who were medically examined before and during the Second World War. Sources used to compile this data set include mainly the German WASt- (Wehrmachtsauskunftstelle für Kriegsverluste und Kriegsgefangene) and BA-ZNS (Bundesarchivzentralnachweisstelle) agencies (Rass, 2003, Rass, 2001). ${ }^{5}$ The WASt agency was one of the authorities in the Third Reich responsible for providing data on soldiers, including name, place of birth, family status, residence, transfers, information on absence, and the date and place of death. The BA-ZNS collected data mostly during registration and physical examination. Additional data compiled by this agency includes general information about soldiers' civil lives, for example ancestry, anthropometric measurements, and religious denomination. We forego using data of foreign-born soldiers, soldiers recruited prior to 1936 , and individuals of whose religious denomination cannot clearly be identified as Protestant or Roman Catholic. ${ }^{6}$ While the reason we only include Protestants and Catholics is straightforward, the reasons for excluding other aforementioned groups are manifold. Prior to the reinstatement of conscription in 1935, the size of German armed forces was limited to 115,000 men and consisted of members probably less representative than those who served as conscripts after 1935. We also excluded non-German soldiers who were drafted

\footnotetext{
5 The geographical distribution of observations in the dataset constitutes a limitation regarding the representativeness. The core Protestant region in Germany is located in the centre and northern regions of historical Germany, although important smaller regional clusters exist in many parts of the country. The dataset used in this study is based on the population of such a mixed region. Also, this dataset does not allow to make any inferences regarding the female or the Jewish population in Germany. Generally, the physiology of adult females allows for more resilience in times of famine compared with men. However, heights are determined during the first years in life and we therefore do not expect a large female advantage.

${ }^{6}$ This latter group refers to small and unknown denominations rather than German Jews. These data do not contain information about the Jewish population group due to persecution in Nazi Germany.
} 
in Germany, such as French nationals from Alsace-Lorrain, Luxembourgians, and Austrians. This measure allows for obtaining a German-only dataset, with analyzed individuals being ethnically homogeneous and stem from the same geographical region. We also have information of the precise place of birth. We are therefore able to eliminate biases related to cultural, institutional and socioeconomic background, enabling the comparison of like with like. This has been an important feature in case studies on biological living standards in the "two Germanies' and the 'two Koreas' (Komlos and Kriwy, 2003, Pak, 2004).

The remaining data set is composed of some 2,800 soldiers mainly from the western part of Germany (see table 3). ${ }^{7}$ We follow Armstrong (1972a) in that we categorize soldiers by father's occupation, assuming that the occupational background of the main income-earner at the time proxies socioeconomic status, human capital and family income. Categories include in ascending order - unskilled, semi-skilled, skilled, semi-professional, and professional; we group all individuals into three clusters in order to obtain categories for low, medium, and high socioeconomic status. In this case, 42.6 per cent stem from a lower socioeconomic background, whereas 42.8 per cent and 14.6 per cent of individuals are associated with a medium and high status, respectively. There are more Catholics than Protestants in the sample, but with a share of 45.2 percent the Protestants cannot be considered a minority. Approximately 28 per cent of individuals have a rural background (defined as villages below 2,000 inhabitants) and approximately 72 per cent live in towns and cities (above this threshold).

Descriptive statistics presented in table 3 also indicate that a large share of individuals in our sample were born during the period 1910- July 1914 (24 per cent), August 1914- June 1919 (30 per cent), and July 1919 - 1924 (45 per cent).

\footnotetext{
7 'West': approximately what today is North Rhine-Westphalia, the northern part of Rhineland-Palatinate and southern part of Lower Saxony; "North": Majority of lower Saxony and other German regions along the Northand Baltic Sea coast. "South": Bavaria, Baden-Wuerttemberg and southern parts of Rhineland-Palatinate; "Central": remaining German territories excluding regions east to Oder and Neisse rivers.
} 
[place table 3 here]

\section{Results: living standards of Protestants and Catholics between 1910 and 1924}

In table 5 the results of a set of regressions is presented. Formula one outlines the basic model estimated by these regressions.

$$
\begin{aligned}
h t_{i}= & \alpha+\beta_{1} * \text { Socioeconomic status }+\beta_{2} * \text { Sibship size }+\beta_{3} * \text { Denomination }+\beta_{4} *(X) \\
& +\beta_{5} *(T)+\varepsilon
\end{aligned}
$$

where $h t_{i}$ denotes individual height in centimeters; the variable sibship size is defined as the number of siblings of individual $i$; a set of binary variables controls for low, medium and high socioeconomic status as well as Protestantism and Catholicism; vector $X$ contains a set of control variables, such as time of medical examination, young age, rural or urban background, an interaction term combining urban background and birth during August 1914 and June 1919 as well as region fixed-effects. In addition, all models include a set of time dummies $(T)$ which identify an individual's birth cohort and help in assessing any height trends over the period under observation.

\footnotetext{
[place table 5 here]
}

We distinguish a pre-war period, 1910 to July 1914, one for the war cohort born during August 1914 and June 1919 and one post-war cohort, July 1919 to 1924, reflecting biological living standards and their changes over time. Model one establishes the fact that German heights experienced a drop during the war period. Individuals born during this period are found to be more than one centimeter shorter than the pre-war cohort and those individuals who were born after the war ended. The rationale behind including these variables is that final average height is mainly a function of a birth cohort's nutritional and health conditions around their time of birth. Average height is sensitive to shocks in nutritional and health standards around a cohort's 
time of birth and therefore reflects changing socioeconomic conditions of the societal groups analyzed.

Model two extends the basic set up by controlling for differences between Protestants and Catholics. The former serves as the reference category while three interaction terms reflect differences between Catholics born before, during and after the war and their Protestant peers. In model two size and level of statistical significance of the coefficients testing for pre-war and post-war differences are reduced; the coefficient testing for a difference between Protestant and Catholics who were born during the war, however, suggests that Catholics who were born during the war were approximately 0.8 centimeter shorter than the corresponding Protestant peer group. Also, controlling for Catholic war-cohort reduces the coefficient representing the general war-cohort dummy and this coefficient is not significantly different from the pre-war coefficient, suggesting that the drop in height found in model one has to be attributed partly to the Catholic community.

In models three and four we aim at explaining the difference between Catholic and Protestant heights by adding controls for socioeconomic factors. The literature suggests that potential differences lie in education, occupational attainment and fertility (Becker et al., 2010, Becker and Woessmann, 2009). The rationale behind this strategy is that there might be differences in socioeconomic features leading to differences in height. Simple descriptive statistics suggest that differences between these groups in terms of occupational status are almost negligible (figure 1; table 4); approximately 14 to 15 per cent of each group is categorized as high-skilled and the share of low-skilled occupations is also very similar. However, Protestants and Catholics differ in one key respect: we find that the latter group's family size is higher - each Protestant in the sample reported to have approximately 2.9 siblings while Catholics reported to have approximately 3.8 siblings on average.

[place table 4 here] 
In model three we take into account evidence that highlight the importance of socioeconomic status and human capital for explaining Protestants' economic success. We control for the socioeconomic background of an individuals, measured by the level of sophistication of fathers' occupations. Individuals are categorized into three socioeconomic groups according to the scheme suggested by Armstrong (1972b): Individuals are identified as having a high socioeconomic background (Armstrong's 'professional' and 'semi-professional' categories), medium socioeconomic background ('skilled'), and low socioeconomic background ('semiskilled' and 'unskilled'). The group we identify having a low socioeconomic status is approximately one centimeter shorter compared to those from a medium background; children from upper societal strata tend to be approximately 1.5 centimeter taller than this reference. More importantly, including this control does not reduce the estimated height difference between Protestant and Catholic war cohorts; in fact, this height difference seems to be unrelated to social class in general.

In another attempt to explain height advantage of Protestant during the war we add a metric variable reflecting the number of siblings of each individual (model four). We find a negative relationship between sibship size and height and each additional sibling reduces the estimated height by 0.2 centimeters. An important feature of this model is the somewhat smaller coefficient of the interaction term identifying Catholics born during the war, suggesting that to some extent height differences might be the result of difference in family size, not socioeconomic background per se. We also tested for an interaction effect of sibship size and birth during the war years, assuming that large families are facing disproportionately more problems to support their children during the war; however, the results presented in model six do not support this hypothesis. Most importantly, despite the inclusion of a proxy for fertility the disproportionately large drop in height of Catholics during the war prevails and this coefficient is statistically significant. The negative coefficient of sibship size is in line with the 
wider body of literature, which suggests the existence of a 'quantity-quality' trade-off where a higher number of siblings is correlated with lower resource provision per child. Conversely, smaller family size has been found to correlate with school enrollment, literacy and occupational attainment (Klemp and Weisdorf, 2012, Becker, 1960, Becker and Lewis, 1973, Becker et al., 2010, Fernihough, 2011). ${ }^{8}$

In addition, all models control for the size of an individuals' place of birth. Rural dwellers often enjoy closer proximity to food production which can result in lower prices paid due to the absence of intermediaries (Baten, 2000, Martínez-Carrión and Moreno-Lázaro, 2007). Especially during the First World War German authorities were keen to enforce the rationing system in attempt to prevent illicit trade, which was concentrated in and around urban areas. Illicit trade was therefore easier in rural regions. On the other hand, West Germany during the period under observation was highly integrated due to modern infrastructure and communication, allowing information and goods to be easily exchanged between rural and urban areas (Baten and Wagner, 2003). As a result, rural dwellers may have also enjoyed lower transaction costs during the time the rationing system was in place, as the authorities were more assertive in urban areas. However, empirical results do not confirm a general disadvantage of urban citizens or even an 'urban penalty'; coefficients differentiating rural and urban backgrounds, and an interaction variable combining rural background and the war cohort are consistently small and statistically insignificant (not shown here).

A set of binary variables identifying the year of medical examination is included to take changing drafting strategies into account. For example, during peacetime physical fitness requirements were often stricter and military services easier to postpone than during wars. We also include controls for individuals who were medically examined at an age younger than 20 . Ex-ante, we do not exactly know at which age individuals are fully grown, but it is likely that

\footnotetext{
${ }^{8}$ Model five test for the impact of socioeconomic status and fertility without controlling for denomination; this exercise shows that these findings are robust to the exclusion of denomination.
} 
younger ages correspond with shorter heights as individuals' height growth process was not yet complete at the time of medical examination. In the case of Germany, under-aged draftees were used as supporting staff in various units, especially towards the end of the war. Moreover, all models include controls for region fixed effects which to capture possible influences related to an individual's region of origin. Including this control is motivated by the concern that characteristics attributed to Protestant abilities are associated with regional characteristics that preceded the Protestant Reformation (Iannaccone, 1998, Samuelsson, 1993, Tawney, 1926). We also address the possibility that Catholics and Protestants are unequally distributed geographically, but that each group possibly tends to live in separate regions within Germany and that characteristics of regions could contribute some explanatory power to the regression models (Basten and Betz, 2013).

\section{Conclusion}

We contribute to the literature on the economics of religion by investigating Protestant and Catholic social institutions. To do so we exploit a natural experiment in Germany during the First World War: the shortage of food and the emergence of black markets. The economic responses of Protestant and Catholic communities to these harsh conditions may help to assess their relative abilities to cope with deteriorating material living conditions.

Using individual height data on some 2,800 Germans from the North-West of Germany as a proxy for levels of malnutrition we investigate living standards of Protestants and Roman Catholics in Germany prior, during and after the First World War. Our results indicate that German height dropped during August 1914 and June 1919 and that a disproportionately large share of this drop can be attributed to Catholics, indicating that inequality between these groups increased during the First World War. Protestants seem to have coped better with economic challenges related to the undersupply of nutritional resources and consumption goods in general, food rationing, and the necessity to engage in illicit trading. For the birth period before 
the First World War and after the Treaty of Versailles we do not find differences in height between Protestants and Catholics. In a set of regression models we try to explain these differences by adding controls for socioeconomic status, the latter being identified using the occupation of an individual's father as a benchmark. Our results suggest that lower-skilled professions correlate with lower heights in general, while the opposite is true for professionals. Importantly, these proxies for socioeconomic status cannot fully explain the Protestant height advantage. Adding a control for the number of siblings and socioeconomic status, however, reduces the estimated height gap between Protestants and Catholics. An important finding of this study is that for the birth cohort of August 1914 to June 1919 we find a statistically significant difference between Protestants and Catholics and this height gap cannot fully be attributed to socioeconomic background and fertility. This finding is the result of a somewhat conservative estimation strategy in that fertility is considered to be exogenous to religious affiliation; if one considered higher fertility as part of the Catholic bundle of institutions the effect of Catholic social institutions on the levels of wellbeing in this historical setting would be larger still.

The findings regarding declining heights and height divergence must be discussed within the historical setting. Generally, there is no evidence for discrimination against on societal group and pregnant women and children from both groups were often provided with extra rations to minimize the detrimental effect of the famine. For example, depending on availability children in the cities of Cologne and Koblenz received extra rations of fresh or condensed milk, rusk and sugar. Towards the end of the war, school children received a dish of soup in the morning to limit starvation and to help them concentrate in class. When rations needed to be cut, authorities tried to favour children on the expense of adults (Bott, 1981). ${ }^{9}$ The very fact that the war cohort was disproportionally well-fed due to the provision of extra rations

\footnotetext{
${ }^{9}$ Bochniak (2009) presents similar evidence for the city of Ulm.
} 
suggests that the population as a whole probably fared worse in comparison; evidence provided in this study therefore probably underestimates the full extent of the famine.

Do the results of this study allow solving the mystery of presumptive superior Protestant abilities? For the period before the war, we cannot observe any statistically significant differences in net-nutritional standards of Protestants and Catholics. If there were any relevant differences in this regard, it required serious food shortages to bring them to light, or at least to allow detecting them with the toolkit of an economist. However, these differences in biological living standards are robust, statistically significant and its magnitude is not negligible if evaluated within the historical setting. In an increasingly industrializing society it is reasonable to assume that any differences in net-nutrition decrease since decreasing returns to nutritional intake reduce the marginal effect on heights (Blum, 2013b); future research will have to address the question whether differences in living standards change over time, i.e. are reduced in the course of economic development.

What is beyond the scope of this study is the criticism brought forward by other authors. Critics often argue that not all Protestant societies have exhibited a work ethic, nor do all societies that have exhibited a work ethic are Protestant ones. Also, many other hypotheses address the question whether some countries are rich and others are not, and the majority of these hypotheses are not addressed by Weber's 'Protestant Ethic'. 


\section{Appendix:}

Figure 1: Occupational background and fertility by societal group

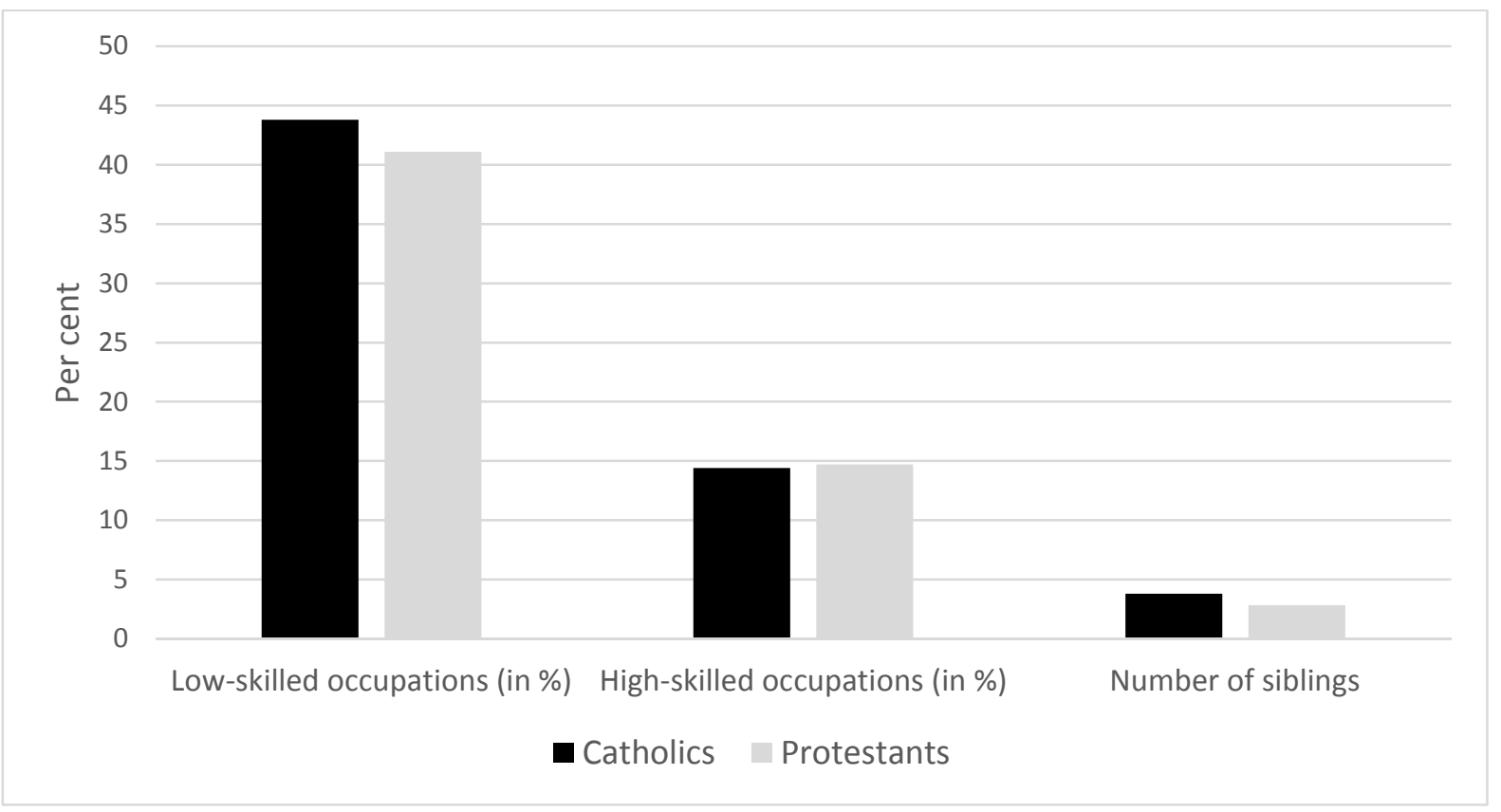


Table 1: Food rations in per cent of pre-war consumption

\begin{tabular}{|l|c|c|c|}
\hline & 07/1916-06/1917 & $\mathbf{0 7 / 1 9 1 7 - 0 6 / 1 9 1 8}$ & $\mathbf{0 7 / 1 9 1 8 - 1 2 / 1 9 1 8}$ \\
\hline Meat & 31 & 20 & 12 \\
\hline Fish & 51 & n/a & 5 \\
\hline Eggs & 18 & 13 & 13 \\
\hline Lard & 14 & 11 & 7 \\
\hline Butter & 22 & 21 & 28 \\
\hline Cheese & 3 & 4 & 15 \\
\hline Rice & 4 & - & - \\
\hline Pulses & 14 & 1 & 7 \\
\hline Sugar & 49 & 61 & 82 \\
\hline Potatoes & 71 & 94 & 94 \\
\hline Vegetable fat & 39 & 41 & 17 \\
\hline Flour & 53 & 47 & 48 \\
\hline
\end{tabular}

Source: Kuczynski (1947) 
Table 2: Official and black market prices for foodstuffs in Essen, 1916-18

\begin{tabular}{|ll|ccc|ccc|ccc|}
\hline & & \multicolumn{4}{|c|}{1916} & \multicolumn{3}{c|}{1917} & \multicolumn{3}{c|}{1918} \\
Product & Unit & official & unofficial & ratio & official & unofficial & ratio & official & unofficial & ratio \\
\hline Wheat flour & $\mathrm{kg}$ & 0.57 & 5.35 & 9.38 & 0.58 & 8.02 & 13.82 & 0.65 & 11.76 & 18.09 \\
Potatoes & $\mathrm{kg}$ & 0.14 & 0.64 & 4.58 & 0.22 & 0.96 & 4.37 & 0.28 & 1.82 & 6.49 \\
Beef & $\mathrm{kg}$ & 5.12 & 10.69 & 2.09 & 4.75 & 17.10 & 3.60 & 4.67 & 21.38 & 4.58 \\
Margarine & $\mathrm{kg}$ & 4.03 & 10.69 & 2.65 & 4.00 & 27.79 & 6.95 & 4.00 & 27.79 & 6.95 \\
Sugar & $\mathrm{kg}$ & 0.64 & 2.67 & 4.18 & 0.68 & 9.62 & 14.15 & 0.90 & 16.04 & 17.82 \\
Eggs & apiece & 0.30 & 0.96 & 3.21 & 0.36 & 3.74 & 10.39 & 0.42 & 5.35 & 12.73 \\
Milk & Litre & 0.31 & 1.07 & 3.45 & 0.41 & 2.14 & 5.21 & 0.53 & 5.35 & 10.09 \\
\hline
\end{tabular}


Table 3 - Characteristics of the sample

Birth regions share $(\%)$

West

91.05

North-West

5.49

South

2.00

Central

1.46

City size

$<2,000$ inhabitants

28.46

$>2,000$ inhabitants

71.54

$\underline{\text { Socioeconomic background }}$

Low

42.61

Medium

42.83

High

14.56

Religious denomination

Roman Catholic

54.77

Protestant

45.23

Birth cohorts

1910 - July 1914

24.05

August 1914 - June 1919

30.46

July 1919 - 24

45.49

Sum

100.00 
Table 4: Occupational background and fertility by societal group

\begin{tabular}{|l|c|c|}
\hline & Catholics & Protestants \\
\hline Low-skilled occupations (in \%) & 43.8 & 41.1 \\
\hline High-skilled occupations (in \%) & 14.4 & 14.7 \\
\hline Number of siblings & 3.79 & 2.85 \\
\hline
\end{tabular}

Note: Low-skilled occupations refer to Armstrong's (1972) 'unskilled' and 'semi-skilled' categories; High-skilled occupations include 'semi-professional' and 'professional' categories. 
Table 5: Determinants of individual height in Germany, 1910-24

\begin{tabular}{|c|c|c|c|c|c|}
\hline & (1) & $(2)$ & (3) & (4) & $(5)$ \\
\hline \multicolumn{6}{|l|}{ Period of birth } \\
\hline Pre-war & reference & reference & reference & reference & reference \\
\hline \multirow[t]{2}{*}{ During WW1 } & $-1.27^{* *}$ & $-1.07^{*}$ & $-1.04 *$ & $-1.08 *$ & $-1.18^{* *}$ \\
\hline & $(-2.41)$ & $(-1.94)$ & $(-1.88)$ & $(-1.96)$ & $(-1.98)$ \\
\hline \multirow[t]{2}{*}{ Post-war } & 0.04 & -0.10 & -0.04 & -0.22 & -0.24 \\
\hline & $(0.10)$ & $(-0.19)$ & $(-0.08)$ & $(-0.43)$ & $(-0.48)$ \\
\hline \multicolumn{6}{|l|}{ Religion } \\
\hline \multirow[t]{2}{*}{ Catholic } & & -0.18 & -0.07 & 0.09 & 0.10 \\
\hline & & $(-0.52)$ & $(-0.20)$ & $(0.26)$ & $(0.30)$ \\
\hline \multirow[t]{2}{*}{ Catholic x WW1 } & & $-0.77^{*}$ & $-0.88^{*}$ & $-0.81 *$ & $-0.90 *$ \\
\hline & & $(-1.67)$ & $(-1.93)$ & $(-1.78)$ & $(-1.86)$ \\
\hline \multirow[t]{2}{*}{ Catholic $\mathrm{x}$ post-war } & & 0.09 & 0.04 & 0.09 & 0.11 \\
\hline & & $(0.21)$ & $(0.10)$ & $(0.20)$ & $(0.26)$ \\
\hline \multicolumn{6}{|l|}{ Socioeconomic Status } \\
\hline Low & & & $\begin{array}{c}-1.02 * * * \\
(-4.01)\end{array}$ & $\begin{array}{c}-0.93 * * * \\
(-3.66)\end{array}$ & $\begin{array}{c}-0.93 * * * \\
(-3.65)\end{array}$ \\
\hline \multicolumn{2}{|l|}{ Medium } & & reference & reference & reference \\
\hline High & & & $\begin{array}{c}1.55^{* * *} \\
(4.13)\end{array}$ & $\begin{array}{c}1.51^{* * *} \\
(4.05)\end{array}$ & $\begin{array}{c}1.51 * * * \\
(4.05)\end{array}$ \\
\hline \multicolumn{6}{|l|}{ Family Size } \\
\hline Sibship size & & & & $\begin{array}{c}-0.20 * * * \\
(-4.51)\end{array}$ & $\begin{array}{c}-0.22 * * * \\
(-3.92)\end{array}$ \\
\hline Sibship size $x$ WW1 & & & & & $\begin{array}{c}0.05 \\
(0.53)\end{array}$ \\
\hline $\begin{array}{l}\text { Controls } \\
\text { Year of medical } \\
\text { examination }\end{array}$ & YES & YES & YES & YES & YES \\
\hline Young age & YES & YES & YES & YES & YES \\
\hline City size & YES & YES & YES & YES & YES \\
\hline Region fixed-effects & YES & YES & YES & YES & YES \\
\hline Constant & $\begin{array}{c}172.80^{* * *} \\
(52.36)\end{array}$ & $\begin{array}{c}173.13^{* * *} \\
(52.79)\end{array}$ & $\begin{array}{c}172.82^{* * *} \\
(55.30)\end{array}$ & $\begin{array}{c}173.02^{* * *} \\
(53.68)\end{array}$ & $\begin{array}{c}173.05^{* * *} \\
(53.50)\end{array}$ \\
\hline Observations & 2,797 & 2,797 & 2,797 & 2,797 & 2,797 \\
\hline R-squared & 0.03 & 0.03 & 0.04 & 0.05 & 0.05 \\
\hline
\end{tabular}

Note: All regressions include robust standard errors. ${ }^{* * *},{ }^{* *}$, and * refer to statistical significance at the $1 \%, 5 \%$, and $10 \%$ level, respectively. Robust t-statistics are shown in parentheses. Controls for city size include an interaction term, identifying individuals who were born during August 1914 and June 1919 in an urban area. 


\section{References}

ACEMOGLU, D., JOHNSON, S. \& ROBINSON, J. 2005. The Rise of Europe Atlantic Trade, Institutional Change and Economic Growth. The American Economic Review, 95, 546-79.

ALLEN, D. W. 2012. The institutional revolution : measurement and the economic emergence of the modern world, Chicago ; London, University of Chicago Press.

ALLEN, K. 1998. Sharing scarcity: Bread rationing and the First World War in Berlin, 1914-1923. Journal of Social History, 32, 371-393.

ARMSTRONG, W. A. 1972a. The use of information about occupation. In: WRIGLEY, E. A. (ed.) Nineteenth-century society: essays in the use of quantitative methods for the study of social data.

ARMSTRONG, W. A. 1972b. The use of information about occupation. In: WRIGLEY, E. A. (ed.) Nineteenth-Century Society: Essays in the Use of Quantitative Methods for

the Study of Social Data. Cambridge: CUP.

ARRUÑADA, B. 2010. Protestants and Catholics: Similar Work Ethic, Different Social Ethic. The Economic Journal, 120, 890-918.

BASTEN, C. \& BETZ, F. 2013. Beyond Work Ethic: Religion , Individual, and Political Preferences. American Economic Journal: Economic Policy, 5, 67-91.

BATEN, J. 2000. Economic development and the distribution of nutritional resources in Bavaria, 1797-1839: an anthropometric study. Journal of Income Distribution, 9, 89-106.

BATEN, J. \& BLUM, M. 2012. Growing Tall but Unequal: New Findings and New Background Evidence on Anthropometric Welfare in 156 Countries, 1810-1989. Economic History of Developing Regions, 27, 66-85.

BATEN, J. \& SCHULZ, R. 2005. Making profits in wartime : corporate profits, inequality, and GDP in Germany during the First World War. The Economic History Review, 58, 34-56.

BATEN, J. \& WAGNER, A. 2003. Autarchy, market disintegration, and health: the mortality and nutritional crisis in Nazi Germany, 1933-1937. Econ Hum Biol, 1, 1-28.

BECKER, G. S. 1960. An Economic Analysis of Fertility. In: BECKER, G. S. (ed.) Demographic and Economic Change in Developed Countries. Princeton: PUP.

BECKER, G. S. \& LEWIS, H. G. 1973. On the Interaction between the Quantity and Quality of Children. Journal of Political Economy, 81, 279-288.

BECKER, S., CINNIRELLA, F. \& WOESSMANN, L. 2010. The trade-off between fertility and education: evidence from before the demographic transition. Journal of Economic Growth, 15, 177-204.

BECKER, S. O. \& WOESSMANN, L. 2009. Was Weber Wrong? A Human Capital Theory of Protestant Economic History. The Quarterly Journal of Economics, 124, 531-596.

BLUM, M. 2011. Government decisions before and during the First World War and the living standards in Germany during a drastic natural experiment. Explorations in Economic History, 48, 556-567.

BLUM, M. 2013a. Culture and Genetic Influences on the 'Biological Standard of Living'. Historical Methods, 46.

BLUM, M. 2013b. The Influence of Inequality on the Standard of Living: Worldwide Anthropometric from the 19th and 20th centuries. Economics and Human Biology, (forthcoming).

BLUM, M. 2013c. War, food rationing, and socioeconomic inequality in Germany during the First World War. Economic History Review, 66, 1063-1083.

BLUM, M. \& ELORANTA, J. (forthcoming). The Economics of Total War and Reconstruction. In: DOUMANIS, N. (ed.) The Oxford Handbook of Early Twentieth-Century Europe. Oxford: Oxford University Press.

BLUM, M., MCLAUGHLIN, E. \& HANLEY, N. 2013. Genuine savings and future well-being in Germany, 1850-2000. University of Stirling Working Paper. Stirling Economics Discussion Paper.

BOCHNIAK, M. 2009. Lebensmittelrationierung in Ulm 1915-1924. Auszüge aus dem Amtsblatt für Stadt und Bezirk Ulm. International Journal of Rationing, 1. 
BOPPART, T., FALKINGER, J. \& GROSSMANN, V. 2014. Protestantism and Education: Reading (the Bible) and Other Skills. Economic Inquiry.

BOPPART, T., FALKINGER, J., GROSSMANN, V., WOITEK, U. \& WÜTHRICH, G. 2013. Under which conditions does religion affect educational outcomes? Explorations in Economic History, 50, 242-266.

BOTT, J. P. 1981. The German Food Crisis of World War I: The Cases of Coblenz and Cologne. PhD, University of Missouri-Columbia.

BROADBERRY, S. N. \& HARRISON, M. 2005. The economics of World War I, Cambridge ; New York, Cambridge University Press.

BUCHANAN, J. M. 1965. An economic theory of clubs. Economica, 32, 1-14.

CANTONI, D. 2013. The Economic Effects of the Protestant Reformation: Testing the Weber Hypothesis in the German Lands. Munich Discussion Paper No. 2013-4.

COLVIN, C. L. 2011. Religion, competition and liability: Dutch cooperative banking in crisis, 1919-1927. $\mathrm{PhD}$, The London School of Economics and Political Science.

COX, M. E. 2015. Hunger games: or how the Allied blockade in the First World War deprived German children of nutrition, and Allied food aid subsequently saved them. The Economic History Review, 68, 600-631.

FEHR, S. 2009. Die "Stickstofffrage" in der deutschen Kriegswirtschaft des Ersten Weltkrieges und die Rolle der neutralen Schweiz, Bern, Verlag Bautz.

FERNIHOUGH, A. 2011. Human capital and the quantity-quality trade-off during the demographic transition: New evidence from Ireland. Working Paper Series, UCD Centre for Economic Research.

FERNIHOUGH, A. \& O'ROURKE, K. H. 2014. Coal and the European industrial revolution. National Bureau of Economic Research.

FLEMMING, J. 1978. Landwirtschaftliche Interessen und Demokratie : ländliche Gesellschaft, Agrarverbände und Staat 1890 - 1925, Bonn, Verl. Neue Ges.

FOGEL, R. W. \& ENGERMAN, S. L. 1974. Time on the cross; the economics of American Negro slavery, Boston,, Little.

HOFFMANN, W. G., GRUMBACH, F. \& HESSE, H. 1965. Das Wachstum der deutschen Wirtschaft seit der Mitte des 19. Jahrhunderts, Berlin, Heidelberg, New York, Springer-Verlag.

HUBER, D. \& FOGEL, E. M. (eds.) 1920. Food conditions and agricultural production.

IANNACCONE, L. R. 1998. Introduction to the Economics of Religion. Journal of economic literature, $1465-1495$.

INGLEHART, R. 1999. Trust, well-being and democracy. In: WARREN, M. (ed.) Democracy and Trust. New York and Cambridge, U.K.: Cambridge University Press.

KLEMP, M. \& WEISDORF, J. 2012. Fecundity, Fertility and Family Reconstitution Data: The Child Quantity-Quality Trade-Off Revisited. CEPR Discussion Papers.

KOMLOS, J. \& BATEN, J. 2004. Looking backward and looking forward - Anthropometric research and the development of Social Science History. Social Science History, 28, 191-210.

KOMLOS, J. \& KRIWY, P. 2003. The Biological Standard of Living in the Two Germanies. German Economic Review, 4, 459-473.

KUCZYNSKI, J. 1947. Die Geschichte der Lage der Arbeiter in Deutschland von 1880 bis in die Gegenwart, Berlin,, Verlag die Freie Gewerkschaft.

LA PORTA, R., LOPEZ-DE-SILANES, F., SHLEIFER, A. \& VISHNY, R. W. 1997. Trust in large organizations. American Economic Review, 87, 333-8.

LANDES, D. S. 1969. The unbound Prometheus: technological change and industrial development in Western Europe from 1750 to the present, London,, Cambridge U.P.

LANGE, J. 1929. Die Lebensmittelversorgung der Stadt Essen während des Krieges. PhD, University of Erlangen.

MARTÍNEZ-CARRIÓN, J.-M. \& MORENO-LÁZARO, J. 2007. Was there an urban height penalty in Spain, 1840-1913? Economics and Human Biology, 5, 144-164. 
MCCLOSKEY, D. N. 2010. Bourgeois dignity : why economics can't explain the modern world, Chicago, University of Chicago Press.

MORISHIMA, M. 1982. Why has Japan succeeded? : western technology and the Japanese ethos, Cambridge Cambridgeshire ; New York, Cambridge University Press.

NORTH, D. C. 1994. Economic performance through time. The American economic review, 359-368.

OFFER, A. 1989. The First World War : an agrarian interpretation, Oxford, Clarendon Press.

PAK, S. 2004. The biological standard of living in the two Koreas. Economics and human biology, 2, 511-521.

RASS, C. 2001. "Menschenmaterial" : Sozialprofil, Machtstrukturen und Handlungsmuster einer Infanteriedivision der Wehrmacht im Zweiten Weltkrieg.

RASS, C. 2003. "Menschenmaterial" : deutsche Soldaten an der Ostfront ; Innenansichten einer Infanteriedivision 1939 - 1945, Paderborn [u.a.], Schöningh.

RENNEBOOG, L. \& SPAENJERS, C. 2012. Religion, economic attitudes, and household finance. Oxford Economic Papers-New Series, 64, 103-127.

RITSCHL, A. 2005. The Pity of Peace: Germany's Economy at War, 1914-1918. In: BROADBERRY, S. N. \& HARRISON, M. (eds.) The Economics of World War I. Cambridge: Cambridge University Press.

ROBINSON, J. A. 2013. Measuring institutions in the Trobriand Islands: a comment on Voigt's paper. Journal of Institutional Economics, 9, 27-29.

SAMUELSSON, K. 1993. Religion and Economic Action: The Protestant Ethic, the Rise of Capitalism, and the Abuses of Scholarship, Toronto, University of Toronto Press.

SCHALTEGGER, C. A. \& TORGLER, B. 2010. Work ethic, Protestantism, and human capital. Economics Letters, 107, 99-101.

SIEGMUND-SCHULTZE, F. 1919. Die Wirkungen der englischen Hungerblockade auf die deutschen Kinder. Die Eiche - Vierteljahrsschrift zur Pflege freundschaftlicher Beziehungen zwischen Großbritannien und Deutschland, Sonderheft, 31.

SKALWEIT, A. 1927. Die deutsche Kriegsernährungswirtschaft, Stuttgart, Deutsche Verlagsanstalt. SPENKUCH, J. L. 2011. The Protestant Ethic and Work: Micro Evidence from Contemporary Germany. STECKEL, R. H. 1995. Stature and the standard of living. Journal of Economic Literature, 33, 19031940.

STULZ, R. M. \& WILLIAMSON, R. 2003. Culture, openness and finance. Journal of Finance Economics, 70, 313-349.

TAWNEY, R. H. 1926. Religion and the Rise of Capitalism, New York, Harper and Row.

VOIGT, S. 2013a. How (not) to measure institutions. Journal of Institutional Economics, 9, 1-26.

VOIGT, S. 2013b. How (not) to measure institutions: a reply to Robinson and Shirley. Journal of Institutional Economics, 9, 35-37.

WEBER, M. 1904. Die protestantische Ethik und der 'Geist' des Kapitalismus. Archiv für Sozialwissenschaft und Sozialpolitik, 20, 1-54.

WEBER, M. 1905. Die protestantische Ethik und der 'Geist' des Kapitalismus. Archiv für Sozialwissenschaft und Sozialpolitik, 21, 1-110.

ZIMMERMANN, W. 1932. Die Veränderungen der Einkommens- und Lebensverhältnisse der deutschen Arbeiter durch den Krieg. In: MEERWARTH, R., GÜNTHER, A. \& ZIMMERMANN, W. (eds.) Die Einwirkung des Krieges auf Bevölkerungsbewegung, Einkommen und Lebenshaltung in Deutschland. Stuttgart. 